ISSN 1392-3196 / e-ISSN 2335-8947

Zemdirbyste-Agriculture, vol. 107, No. 4 (2020), p. 309-316

DOI 10.13080/z-a.2020.107.039

\title{
The response of Medicago sativa to mobile aluminium toxicity at seedling stage
}

\author{
Aurelija LIATUKIENE ${ }^{1}$, Vytautas RUZGAS ${ }^{1}$, Zilvinas LIATUKAS ${ }^{1}$, Regina SKUODIENE ${ }^{2}$ \\ ${ }^{1}$ Lithuanian Research Centre for Agriculture and Forestry, Institute of Agriculture \\ Instituto 1, Akademija, Kèdainiai distr., Lithuania \\ E-mail: aurelija.liatukiene@lammc.lt \\ ${ }^{2}$ Lithuanian Research Centre for Agriculture and Forestry, Vėžaičiai Branch \\ Gargždų 29, Vèžaičiai, Klaipėda distr., Lithuania
}

\begin{abstract}
Aluminium (Al) toxicity is a major limiting factor of crop production in acidic soils. The objective of the current study was to evaluate the development of lucerne (Medicago sativa L.) cultivars and their response to mobile Al toxicity. Three screening methods: filter paper-based, hydroponic and soil-based, were used to assess 13 M. sativa cultivars for their tolerance of mobile Al. Major biological indicators used to analyse mobile Al tolerance were hypocotyl length, root length and root and hypocotyl tolerance index. Toxic effects of mobile Al manifested themselves on all the biological indicators tested, which was shown by the correlations between the biological indicators and screening methods. Under filter paper-based method, the root and hypocotyl tolerance index ranged from $0.0 \%$ to $23.2 \%$ and from $0.0 \%$ to $37.2 \%$, respectively at $16 \mathrm{mM} \mathrm{AlCl}_{3}$ (aluminium chloride). Greater differences in $M$. sativa cultivars' tolerance to mobile Al toxicity were identified between the hydroponic and soil-based methods. In the hydroponic method, the root and hypocotyl tolerance index ranged from $41.0 \%$ to $78.2 \%$ and from $62.1 \%$ to $90.2 \%$, respectively at $50 \mu \mathrm{M} \mathrm{AlCl}_{3}$. Under the soil-based method, hypocotyls were more damaged by $\mathrm{Al}$ toxicity compared with roots at soil $\mathrm{pH} 4.5$ and 4.3. The root and hypocotyl tolerance index at $\mathrm{pH}$ 4.5 was $73.5 \%$ and $39.3 \%$, at $\mathrm{pH} 4.3-35.6 \%$ and $26.3 \%$, respectively. The cultivars 'Mriia odes'ka', 'Romagnola', 'Kunsmme' and 'Juurlu' were distinguished by the highest root and hypocotyl tolerance index under hydroponic and soil-based methods. 'Žydrūnè', 'Birute', 'Magnat', 'Viktoria' and 'Magda' were distinguished by root and hypocotyl tolerance index under hydroponic method. The root tolerance index of these cultivars was the highest under filter paper-based method. These cultivars are considered as tolerant accessions and may be used as donors in breeding for $\mathrm{Al}$ toxicity tolerance.
\end{abstract}

Key words: lucerne, aluminium toxicity, hypocotyl, root, screening method, tolerance index.

\section{Introduction}

Lucerne (Medicago sativa L.) is the world's most important forage crop adapted to a wide range of environments. It is a deep-rooted perennial legume, grown as a high-quality animal feed on a wide range of soils, including acid soils, and is adapted to a wide range of ecological conditions (Bouton, 2012; Sabanci et al., 2013). M. sativa productivity is affected by reduced root growth due to soil acidity and mobile aluminium (Al) toxicity (Khu et al., 2012). Plants depend on their root systems for their survival in nature and for their yield and nutritional quality in agriculture. Root systems are complex, and a variety of traits have been identified over the past decade as contributing to adaptation to low fertility and toxic soils (Idupulapati et al., 2016). Plant root systems comprise a set of phenes, or traits, that interact with the environment, and phenes are the identifiable units of the plant phenotype (York et al.,
2013). Phenotypic characterization of root adaptations to soils with low fertility and mobile Al toxicity is enabling plant breeders to develop cultivars that not only yield more but also contribute to yield stability and nutritional security in the face of climate variability (Idupulapati et al., 2016).

Approximately $40 \%$ of arable soils worldwide are acidic and rhizotoxicity of mobile $\mathrm{Al}$ is the primary limitation to crop and forage yields on most acid soils (Kochian et al., 2015). Recurrent selection based on field performance has been used to develop acid soiltolerant germplasm (Khu et al., 2013). Field screening for mobile Al resistance would seem to be the most desirable approach, because it best approximates the intended cropping environment (Haling et al., 2011; Yang et al., 2013). However, in practice reliable ranking of accessions in the field has been difficult. This is

Please use the following format when citing the article:

Liatukiene A., Ruzgas V., Liatukas Z., Skuodiene R. 2020. The response of Medicago sativa to mobile aluminium toxicity at seedling stage. Zemdirbyste-Agriculture, 107 (4): 309-316. DOI 10.13080/z-a.2020.107.039 
mainly, because mobile Al levels are not uniform, and environmental factors may interact with soil mobile Al to mask the expression of $\mathrm{Al}$ resistance. Thus, it is necessary to combine field with greenhouse screening techniques based on physiological traits of mobile Al resistance (Rao, 2014).

Al tolerance in $M$. sativa can be evaluated using a callus bioassay and whole plant assay in media (Khu et al., 2012), hydroponic system (Narasimhamoorthy et al., 2007), soil-based evaluations comparing growth in unlimed and limed soil (Khu et al., 2012) and Petri dish method (Pan et al., 2008). The different phenotyping methods often give different results suggesting that multiple evaluations at the cell and whole plant level should be used to ascertain variation in the Al tolerance response (Narasimhamoorthy et al., 2007).

The callus bioassay is useful to determine mobile Al tolerance at the cell-based level, while the whole plant assay in media evaluates plant mobile Al tolerance responses and enables examination of root growth variation in response to different growing conditions. The whole plant assay in media is less time and labour consuming compared to previous soil-based assay (Khu et al., 2012). The whole plant assay in media enables the identification of phenotyping differences due to mobile $\mathrm{Al}$ exclusion mechanisms in the root area providing an advantage over hydroponic evaluation systems, in which molecules generated by a particular accession are freely diffused in the growth solution.

All screening methods of tolerance to mobile Al toxicity are associated with selection of tolerant accessions. However, cultivars respond differently to different screening methods for mobile Al toxicity. Cultivars developed in the countries with warm and hot climates are more tolerant of acidic soils and mobile Al. European $M$. sativa cultivars are more sensitive to exposure to acid soils and mobile $\mathrm{Al}$, which causes a drastic decrease in crop density. Single surviving plants of these cultivars are considered the most resistant.

In current research, identification of the most promising cultivars tolerant of acid soils and mobile Al by applying selection methods was expected. Selection of Al-tolerant plants and their cultivation on a large scale have been envisioned as an alternative to overcome $\mathrm{Al}$ toxicity.

In the current study, an attempt was made to determine the effect of toxic levels of mobile $\mathrm{Al}$ on $M$. sativa seedling characters and screen $M$. sativa cultivars for mobile Al toxicity at the seedling stage using root and hypocotyl tolerance index. The objective of this experiment was to evaluate the development of $M$. sativa cultivars exposed to mobile Al toxicity by using three screening methods.

\section{Materials and methods}

An experiment was carried out during 20172018 at Institute of Agriculture Lithuanian Research Centre of Agriculture and Forestry. Filter paper-based, hydroponic and soil-based assays were used to screen for aluminium (Al) tolerance in 13 lucerne (Medicago sativa $\mathrm{L}$.) cultivars. The material subjected to Al resistance tests included cultivars of distinct country origin: 'Birute' and 'Žydrūnè' from Lithuania, 'Ellerskie I' from Canada, 'Juurlu', 'Elda' and 'Kunsmme' from Estonia, 'Alina' and 'Magnat' from Romania, 'Mriia odes'ka' from Ukraine, 'Romagnola' from Italy and 'Viktoria' and 'Magda' from Czech Republic.
Filter paper-based screening method. The screening procedure was derived from Pan et al. (2008) with some modification. Well-developed $M$. sativa seeds of similar size were scarified, the surface sterilized in the solution of $10 \% \mathrm{NaClO}$ (sodium hypochlorite) for $30 \mathrm{~min}$ and rinsed three times in distilled water. The seeds were sown in 90-mm sterile Petri dishes containing two pieces of sterilized filter paper and $7 \mathrm{ml}$ of sterilized $50 \mathrm{mM} \mathrm{CaCl}_{2}(\mathrm{pH} 4.5)$ with five concentrations of $\mathrm{AlCl}_{3}$ (aluminium chloride): 0, 2, 4, 8 and $16 \mathrm{mM}$. Thirty seeds were placed on the filter paper with three replicate dishes per treatment. The experiment was repeated twice. Petri dishes were incubated at $25^{\circ} \mathrm{C}$ temperature in the dark. After four days, the photoperiod was adjusted to $12 / 12 \mathrm{~h}$ (day/night) at $25 / 20^{\circ} \mathrm{C}$ temperature, respectively. After three days, germinated seeds were counted, and root and hypocotyl lengths of the seedlings were measured. The percent of germination was calculated as a ratio of germinated seeds to not-germinated ones. The root and hypocotyl tolerance index was calculated as the maximum root and hypocotyl length in $\mathrm{Al}$ stress culture divided by the root and hypocotyl length in the control treatment at $0 \mathrm{mM} \mathrm{AlCl}_{3}$.

Hydroponic screening method. The screening procedure was derived from Zhang et al. (2007) with some modification. Well-developed $M$. sativa seeds of similar size were scarified, and surface sterilized in solution of $3 \% \mathrm{NaClO}$ for $7 \mathrm{~min}$. After thorough rinsing with sterile distilled water, the seeds were imbibed in sterile water and kept in the dark overnight at $4^{\circ} \mathrm{C}$ temperature. The imbibed seeds were then cold treated by placing on moist filter paper in a Petri dish and incubating for at least $48 \mathrm{~h}$ at $4^{\circ} \mathrm{C}$ temperature. After cold treatment, the seeds were germinated in the dark at $24^{\circ} \mathrm{C}$ temperature for $24 \mathrm{~h}$. Germinated seedlings were transferred to hydroponics in a growth room and grown under an 18/6 h light/dark regime at a constant temperature of $23^{\circ} \mathrm{C}$. The hydroponic system consisted of multiple tanks with 25 -L capacity. Twenty seedlings of each cultivar were placed into four plastic meshbottomed cups. Two cups of each cultivar were placed on a plastic rack that floated on the medium modified with $\mathrm{Al}$ and two cups on the medium without $\mathrm{Al}$. The media were aerated with a small aquarium air pump for 15 min once per hour. The media were maintained at $\mathrm{pH}$ 4.3 by adding $1 \mathrm{M} \mathrm{HCl}$ (hydrochloric acid) as necessary throughout the experiment. After 5 days of growth in hydroponics with five mobile $\mathrm{Al}$ concentrations: $0,5,15$, 25 and $50 \mu \mathrm{M} \mathrm{AlCl}_{3}$, the seedlings were removed, and root and hypocotyl lengths were measured. The root and hypocotyl tolerance index of 13 cultivars was calculated as the maximum root and hypocotyl length in Al stress culture divided by the root and hypocotyl length in the control treatment at $0 \mu \mathrm{M} \mathrm{AlCl}$. The experiment was repeated twice.

The Blade's medium was modified to contain:

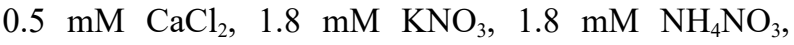
$30.4 \mu \mathrm{M} \mathrm{MgSO}_{4} \times 7 \mathrm{H}_{2} \mathrm{O}, 22 \mu \mathrm{M} \mathrm{KH}_{2} \mathrm{PO}_{4}, 13 \mu \mathrm{M} \mathrm{FeSO}_{4}$, $31.7 \mu \mathrm{M} \mathrm{Ca}\left(\mathrm{NO}_{3}\right)_{2}, 66 \mu \mathrm{M} \mathrm{KCl}, 26 \mu \mathrm{M} \mathrm{NaCl}, 26 \mu \mathrm{M}$ $\mathrm{H}_{3} \mathrm{BO}_{3}, 26 \mu \mathrm{M} \mathrm{MnSO}{ }_{4} \times \mathrm{H}_{2} \mathrm{O}, 5.2 \mu \mathrm{M} \mathrm{ZnSO} \mathrm{Zn}_{4} \times 7 \mathrm{H}_{2} \mathrm{O}$ and $4.8 \mu \mathrm{M} \mathrm{KJ}$.

Soil-based screening method in greenhouse conditions. The screening procedure was derived from Petcu et al. (2006). Physico-chemical properties of soil were: texture-loam, $\mathrm{pH} 7.2-7.5, \mathrm{P} 87.6-117.7 \mathrm{mg} \mathrm{kg}^{-1}$ and $\mathrm{K} 83.8-145.2 \mathrm{mg} \mathrm{kg}^{-1}$. The soil samples of Endocalcari Epigleyic Cambisol (WRB, 2014) and aluminium salt as aluminium sulphate $\left(\mathrm{Al}_{2}\left(\mathrm{SO}_{4}\right)_{3}\right)$ were used for the 
research. The $\mathrm{Al}_{2}\left(\mathrm{SO}_{4}\right)_{3}$ is very soluble in water, therefore, an acidic solution was easily prepared. Using different concentrations of $\mathrm{Al}_{2}\left(\mathrm{SO}_{4}\right)_{3}$, soil treatments with different $\mathrm{pH}$ were obtained. The soil samples were analysed for mobile $\mathrm{Al}$ content, $\mathrm{pH}, \mathrm{P}$ and $\mathrm{K}$ content under laboratory conditions (Table 1).

Table 1. Properties of soil samples with different mobile $\mathrm{Al}$ concentrations

\begin{tabular}{ccccc}
\hline $\mathrm{Al}_{2}\left(\mathrm{SO}_{4}\right)_{3}$ & $\mathrm{pH}$ & $\mathrm{P}$ & $\mathrm{K}$ & $\mathrm{Al}$ \\
\cline { 3 - 5 } content $\mathrm{g}$ & & & $\mathrm{mg} \mathrm{kg}^{-1}$ & \\
\hline 0.0 & 7.2 & 113.4 & 141.9 & 0.0 \\
3.5 & 6.6 & 109.4 & 142.8 & 0.0 \\
5.0 & 6.0 & 79.8 & 132.8 & 0.0 \\
11.9 & 4.5 & 74.1 & 53.9 & 732.5 \\
23.8 & 4.3 & 52.3 & 37.3 & 4594 \\
\hline
\end{tabular}

This experiment was conducted in greenhouse and under laboratory conditions with $M$. sativa plants grown in alkaline $(\mathrm{pH} 7.2)$, neutral $(\mathrm{pH}$ 6.6), slightly acidic (pH 6.0) and highly acidic (pH 4.5 and 4.3) soil Two rows and 15 to 20 seeds were sown in each cup and covered with $60 \mathrm{~g}$ of sand. One cup was one replication. Three replications were used in the experiment. The cups were watered by weight of $70 \%$ field capacity with distilled water every 3 to 4 days and kept under laboratory conditions. One week after emergence, the seedlings were randomly thinned to 10 per row and grown in the greenhouse. Plants were harvested 35 days after sowing, roots were rinsed with tap water, and length of the main root and hypocotyls was measured.

Root and hypocotyl tolerance index was measured: (the root and hypocotyl length in acid soil $/$ the root and hypocotyl length in neutral soil) $\times 100$ was scored. The root and hypocotyl length on each $\mathrm{Al}$ concentration was compared with root and hypocotyl length of the control soil pH 7.2.

Soil agrochemical characteristics were determined by the following methods: the soil $\mathrm{pH}_{\mathrm{KCl}}$ was measured by the potentiometric method in the extraction of $1 \mathrm{M} \mathrm{KCl}$ according to ISO 10390:2005 (Soil quality Determination of $\mathrm{pH}$ ); $\mathrm{P}$ and $\mathrm{K}$ contents were calculated by multiplying mobile $\mathrm{P}_{2} \mathrm{O}_{5}$ and mobile $\mathrm{K}_{2} \mathrm{O}$ contents by 0.436 and 0.830 coefficients, respectively. Mobile $\mathrm{P}_{2} \mathrm{O}_{5}$ and $\mathrm{K}_{2} \mathrm{O}$ contents in the soil were determined using the Egner-Riehm-Domingo (A-L) method. Exchangeable Al content in the soil was determined by the ISO 14254:2018
(Soil quality - Determination of exchangeable acidity using barium chloride solution as extractant).

Statistical analysis. The length of roots and hypocotyls of $M$. sativa cultivars depending on the differences in Al concentrations was calculated, oneway analysis of variance (ANOVA) was used followed by Fisher's least significant difference tests; $P$-values $<0.05$ were considered significant. A two-way ANOVA was performed to determine the effects of factors in two separate pairs (cultivars $\times \mathrm{Al}$ concentration of root length and cultivars $\times \mathrm{Al}$ concentration of hypocotyl length). All data presented are the mean values of three independent sets of experiments ( \pm bars denote standard error, SE). The correlations between experimental data were investigated using liner regression analysis with the statistical program SAS Enterprise Guide, version 7.13 (SAS Institute Inc., USA).

\section{Results and discussion}

The classic symptoms of $\mathrm{Al}$ toxicity are inhibition of root growth and reduction in root penetration and branching, which were observed in the study conducted by Scheffer-Basso and Priori (2015). The analysis of variance (ANOVA) revealed significant differences in all screening methods. A significant difference between cultivars was determined using filter paper-based method, concentrations of mobile $\mathrm{Al}$ and an interaction between Al levels and cultivars for root and hypocotyl lengths (Table 2). Also, significant differences were revealed between cultivars, concentrations and an interaction between $\mathrm{Al}$ concentrations and root length of cultivars. However, the interaction between mobile Al levels and cultivars was not found for hypocotyl length when using hydroponic method. Significant differences between $\mathrm{pH}$ of soils for root lengths were determined under soil-based method. Also, significant differences were determined between cultivars and soil $\mathrm{pH}$ for hypocotyl length.

The root and hypocotyl growth was very slow at the highest mobile $\mathrm{Al}$ concentration under filter paperbased and hydroponic methods. The development of roots and hypocotyls was most affected by the highest mobile Al concentration: compared with the control treatment $\left(0 \mathrm{mM}\right.$ and $\left.0 \mu \mathrm{M} \mathrm{AlCl}_{3}\right)$, it was 11.5 and 11.8 , and 2.0 and 1.4 times lower, respectively. The elongation

Table 2. Analysis of variance (ANOVA) of Medicago sativa cultivars' response to mobile Al toxicity

\begin{tabular}{|c|c|c|c|c|c|c|}
\hline \multirow[b]{4}{*}{ Sum of squares } & \multicolumn{6}{|c|}{ Filter paper-based screening method } \\
\hline & \multicolumn{3}{|c|}{ root length } & \multicolumn{3}{|c|}{ hypocotyl length } \\
\hline & cultivar & $\mathrm{Al}$ & cultivar $\times \mathrm{Al}$ & cultivar & $\mathrm{Al}$ & cultivar $\times \mathrm{Al}$ \\
\hline & 365.8 & 6746.8 & 703.9 & 852.3 & 3435.1 & 527.7 \\
\hline Degree of freedom & 12 & 4 & 48 & 12 & 4 & 48 \\
\hline Mean square & 30.5 & 1686.7 & 14.7 & 71.0 & 858.8 & 11.0 \\
\hline$F$-ratio & 4.3 & 239.3 & 2.1 & 21.7 & 262.6 & 3.4 \\
\hline$P$-value & 0.0001 & 0.0000 & 0.0030 & 0.0000 & 0.0000 & 0.0000 \\
\hline \multicolumn{7}{|c|}{ Hydroponic screening method } \\
\hline & \multicolumn{3}{|c|}{ root length } & \multicolumn{3}{|c|}{ hypocotyl length } \\
\hline & cultivar & $\mathrm{Al}$ & cultivar $\times \mathrm{Al}$ & cultivar & $\mathrm{Al}$ & cultivar $\times \mathrm{Al}$ \\
\hline Sum of squares & 2144.7 & 7184.05 & 1067.1 & 1764.8 & 888.9 & 258.3 \\
\hline Degree of freedom & 12 & 4 & 48 & 12 & 4 & 48 \\
\hline Mean square & 178.7 & 1796.0 & 22.2 & 147.1 & 222.2 & 5.4 \\
\hline$F$-ratio & 20.1 & 201.5 & 2.5 & 24.1 & 36.4 & 0.9 \\
\hline$P$-value & 0.0000 & 0.0000 & 0.0000 & 0.0000 & 0.0000 & 0.6858 \\
\hline \multicolumn{7}{|c|}{ Soil-based screening method } \\
\hline & \multicolumn{3}{|c|}{ root length } & \multicolumn{3}{|c|}{ hypocotyl length } \\
\hline & cultivar & $\mathrm{pH}$ & cultivar $\times \mathrm{pH}$ & cultivar & $\mathrm{pH}$ & cultivar $\times \mathrm{pH}$ \\
\hline Sum of squares & 36.2 & 1282.69 & 96.0 & 163.1 & 1528.8 & 169.0 \\
\hline Degree of freedom & 12 & 4 & 48 & 12 & 4 & 48 \\
\hline Mean square & 3.0 & 320.7 & 20.0 & 13.6 & 382.2 & 3.5 \\
\hline$F$-ratio & 1.5 & 155.4 & 1.0 & 4 & 115.1 & 1.1 \\
\hline$P$-value & 0.1628 & 0.0000 & 0.5401 & 0.001 & 0.0000 & 0.4091 \\
\hline
\end{tabular}


of roots and hypocotyls in acid soil ( $\mathrm{pH} 4.3$ ) was 2.8 and 3.9 times lower, respectively compared with the control treatment ( $\mathrm{pH} 7.2)$ (Table 3).
Filter paper-based screening method. The Al tolerance of plants is commonly evaluated during seedling stage, which might be more critical than later

Table 3. The root and hypocotyl length ( $\mathrm{mm}$ ) of Medicago sativa using three screening methods

\begin{tabular}{ccccccccc}
\hline \multicolumn{2}{c}{ Filter paper-based method } & \multicolumn{2}{c}{ Hydroponic method } & \multicolumn{3}{c}{ Soil-based method } \\
\hline $\begin{array}{c}\mathrm{AlCl}_{3} \mathrm{mM} \\
\text { concentration }\end{array}$ & $\begin{array}{c}\text { root } \\
\text { length }\end{array}$ & $\begin{array}{c}\text { hypocotyl } \\
\text { length }\end{array}$ & $\begin{array}{c}\mathrm{AlCl}_{3} \mu \mathrm{M} \\
\text { concentration }\end{array}$ & $\begin{array}{c}\text { root } \\
\text { length }\end{array}$ & $\begin{array}{c}\text { hypocotyl } \\
\text { length }\end{array}$ & $\mathrm{pH}$ & $\begin{array}{c}\text { root } \\
\text { length }\end{array}$ & $\begin{array}{c}\text { hypocotyl } \\
\text { length }\end{array}$ \\
\hline 0 & $21.8 \mathrm{~d}$ & $16.5 \mathrm{e}$ & 0 & $34.5 \mathrm{e}$ & $22.6 \mathrm{~d}$ & 7.2 & $14.5 \mathrm{~d}$ & $12.2 \mathrm{e}$ \\
2 & $10.2 \mathrm{c}$ & $11.2 \mathrm{~d}$ & 5 & $30.3 \mathrm{~d}$ & $21.2 \mathrm{~cd}$ & 6.6 & $12.5 \mathrm{c}$ & $8.9 \mathrm{c}$ \\
4 & $5.0 \mathrm{~b}$ & $7.7 \mathrm{c}$ & 15 & $24.6 \mathrm{c}$ & $20.1 \mathrm{bc}$ & 6.0 & $11.8 \mathrm{c}$ & $10.4 \mathrm{~d}$ \\
8 & $3.6 \mathrm{ab}$ & $5.2 \mathrm{~b}$ & 25 & $21.4 \mathrm{~b}$ & $18.6 \mathrm{~b}$ & 4.5 & $10.6 \mathrm{~b}$ & $4.7 \mathrm{~b}$ \\
16 & $1.9 \mathrm{a}$ & $1.4 \mathrm{a}$ & 50 & $17.6 \mathrm{a}$ & $16.4 \mathrm{a}$ & 4.3 & $5.2 \mathrm{a}$ & $3.1 \mathrm{a}$ \\
\hline
\end{tabular}

Note. Values within a column followed by the same letter are not significantly different $(P>0.05)$.

stages of growth (Meriño-Gergichevich et al., 2010). The Al toxicity is associated with severe changes in root morphology. Briefly, it results in curved, swollen, cracked, brownish, stubby and stiff root apices. The criteria most often utilized for evaluating Al toxicity are measurements of the growth, number, colour and branching pattern of the root (Scheffer-Basso, Priori,
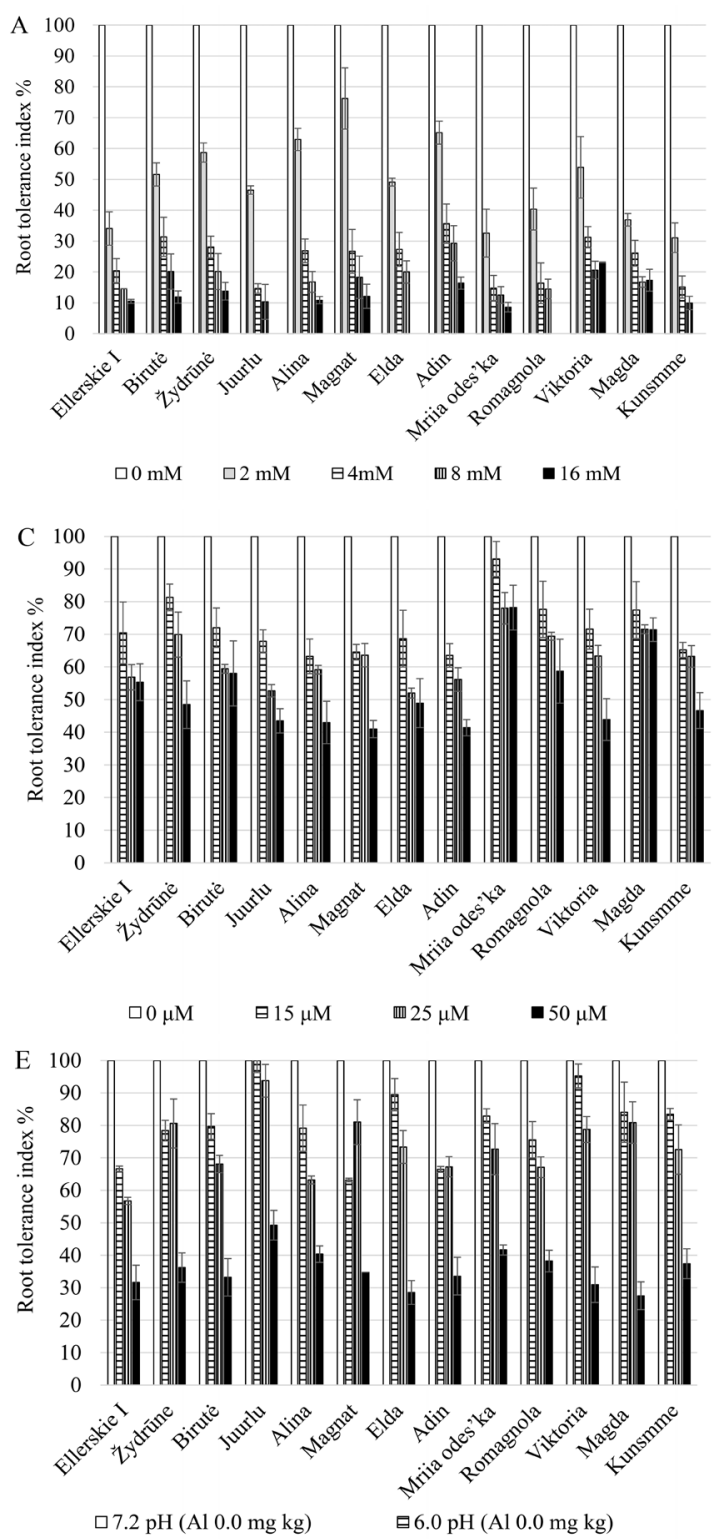

Note. \pm bars denote SE of the mean.
2015). In our experiment, it was clear that $\mathrm{Al}$ inhibited root and hypocotyl elongation of $M$. sativa (Fig.). Those effects become much more evident with increased $\mathrm{Al}$ concentrations (Pan et al., 2008).

Root and hypocotyl length of the control treatment ranged between $11.8-35.0$ and $10.8-24.3 \mathrm{~cm}$, respectively. At the low $\left(0,2\right.$ and $\left.4 \mathrm{mM} \mathrm{AlCl}_{3}\right) \mathrm{Al}$
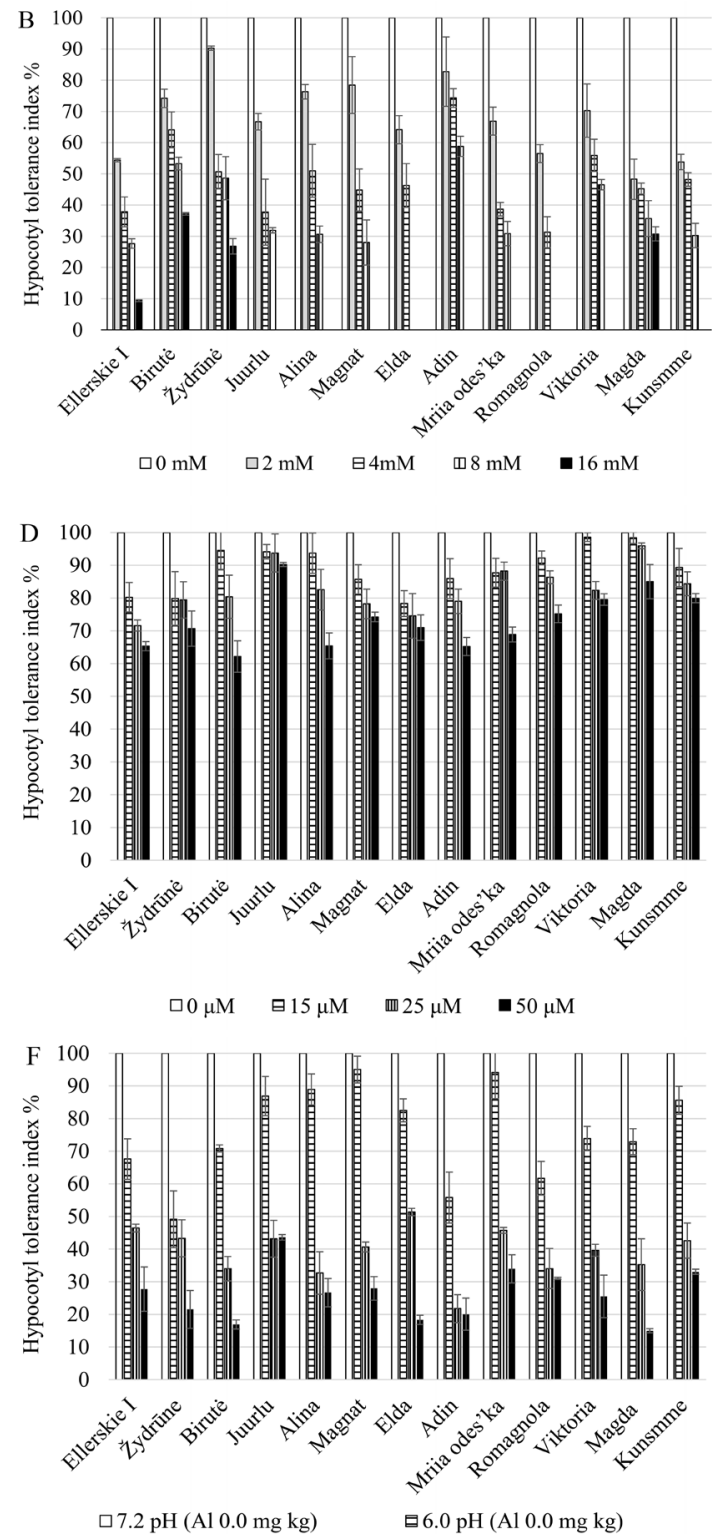

Figure. The root and hypocotyl tolerance index of Medicago sativa using three screening methods: filter paperbased (A, B), hydroponic (C, D) and soil-based (E, F) 
concentrations, the hypocotyl and root length significantly differed (Table 3 ). The root lengths of the cultivars were more similar than hypocotyl lengths at $0 \mathrm{mM} \mathrm{AlCl}$. Among the tested cultivars, root and hypocotyl growth was more inhibited at 8 and $16 \mathrm{mM} \mathrm{AlCl}_{3}$ (Table 4).

At $8 \mathrm{mM} \mathrm{AlCl}_{3}$ concentration, the root and hypocotyl length was 6.0 and 3.2 times lower, respectively compared with the control $(0 \mathrm{mM} \mathrm{AlCl})$; at $16 \mathrm{mM}$ $\mathrm{AlCl}_{3}$ concentration it was 11.4 and 11.7 times lower, respectively compared with the control $(0 \mathrm{mM} \mathrm{AlCl})_{3}$ (Table 3). The decrease in root and hypocotyl growth may be due to the role of $\mathrm{Al}$ in causing plant etiolation and reducing bicipital auxin flow in distal part of the transition zone (Zhang et al., 2014). As a part of natural selection, plants have evolved some specific mechanism to cope with Al toxicity (Arunakumara et al., 2013).

The resistant cultivars 'Birutè', 'Žydrūnè', 'Adin', 'Magnat', 'Viktoria' and 'Magda' showed the best results of root tolerance index at $16 \mathrm{mM} \mathrm{AlCl}_{3}$ : it was 11.9 , 13.8, 16.4, 12.1, 23.2 and $17.3 \%$, respectively (Fig. A). However, 'Birutè', 'Žydrūne' and 'Magda' showed the best hypocotyl tolerance index at $16 \mathrm{mM} \mathrm{AlCl}_{3}$. The hypocotyl tolerance index of these cultivars ranged from $26.8 \%$ to $37.2 \%$ at $16 \mathrm{mM} \mathrm{AlCl}_{3}$ (Fig. B). The sensitive cultivars 'Elda' and 'Romagnola' did not elongate hypocotyls at 8 and $16 \mathrm{mM} \mathrm{AlCl}_{3}$. Also, the roots did not elongate at $16 \mathrm{mM} \mathrm{AlCl}_{3}$. The 'Juurlu' did not elongate hypocotyls and roots at $16 \mathrm{mM} \mathrm{AlCl}_{3}$ (Table 4).

Table 4. The root and hypocotyl length ( $\mathrm{mm})$ of Medicago sativa using filter paper-based screening method

\begin{tabular}{|c|c|c|c|c|c|c|c|}
\hline \multirow{3}{*}{ Cultivar } & \multirow{3}{*}{$\begin{array}{l}\text { Country } \\
\text { of origin }\end{array}$} & \multicolumn{6}{|c|}{$\mathrm{AlCl}_{3} \mathrm{mM}$ concentration } \\
\hline & & 0 & 8 & 16 & 0 & 8 & 16 \\
\hline & & \multicolumn{3}{|c|}{ root length } & \multicolumn{3}{|c|}{ hypocotyl length } \\
\hline Ellerskie I & Canada & $24.9 \mathrm{bc}$ & $3.6 \mathrm{a}-\mathrm{e}$ & $2.6 \mathrm{bcd}$ & $20.4 \mathrm{~cd}$ & $5.6 \mathrm{bcd}$ & $1.9 \mathrm{~b}$ \\
\hline Birutè & Lithuania & $24.5 \mathrm{bc}$ & $4.9 \mathrm{de}$ & 2.9 cde & $18.7 \mathrm{bc}$ & $10.0 \mathrm{e}$ & $7.0 \mathrm{e}$ \\
\hline Žydrūnè & Lithuania & $25.4 \mathrm{bc}$ & $5.1 \mathrm{e}$ & $3.5 \mathrm{ef}$ & $20.9 \mathrm{~cd}$ & $10.2 \mathrm{e}$ & $5.6 \mathrm{~d}$ \\
\hline Juurlu & Estonia & $21.8 \mathrm{ab}$ & $2.3 \mathrm{a}$ & $0.0 \mathrm{a}$ & $12.5 \mathrm{a}$ & $4.0 \mathrm{~b}$ & $0.0 \mathrm{a}$ \\
\hline Alina & Romania & $16.5 \mathrm{ab}$ & $2.8 \mathrm{ab}$ & $1.8 \mathrm{~b}$ & $14.4 \mathrm{ab}$ & $4.4 \mathrm{bc}$ & $0.0 \mathrm{a}$ \\
\hline Magnat & Romania & $17.7 \mathrm{ab}$ & $3.2 \mathrm{a}-\mathrm{c}$ & $2.1 \mathrm{bc}$ & $20.3 \mathrm{~cd}$ & $5.7 \mathrm{bcd}$ & $0.0 \mathrm{a}$ \\
\hline Elda & Estonia & $18.6 \mathrm{ab}$ & $3.7 \mathrm{a}-\mathrm{e}$ & $0.0 \mathrm{a}$ & $12.7 \mathrm{a}$ & $0.0 \mathrm{a}$ & $0.0 \mathrm{a}$ \\
\hline Adin & Romania & $11.8 \mathrm{a}$ & $3.5 \mathrm{a}-\mathrm{d}$ & $1.9 \mathrm{~b}$ & $10.8 \mathrm{a}$ & $6.3 \mathrm{~cd}$ & $0.0 \mathrm{a}$ \\
\hline Mriia odes'ka & Ukraine & $35.0 \mathrm{c}$ & 4.4 def & $3.0 \mathrm{de}$ & $24.3 \mathrm{~d}$ & $7.5 \mathrm{~d}$ & $0.0 \mathrm{a}$ \\
\hline Romagnola & Italy & $26.7 \mathrm{bc}$ & $3.9 \mathrm{~b}-\mathrm{e}$ & $0.0 \mathrm{a}$ & $21.6 \mathrm{~cd}$ & $0.0 \mathrm{a}$ & $0.0 \mathrm{a}$ \\
\hline Viktoria & Czech Republic & $17.3 \mathrm{ab}$ & $3.6 \mathrm{a}-\mathrm{e}$ & $4.0 \mathrm{f}$ & $11.7 \mathrm{a}$ & $5.4 \mathrm{bcd}$ & $0.0 \mathrm{a}$ \\
\hline Magda & Czech Republic & $19.6 \mathrm{ab}$ & $3.3 \mathrm{abc}$ & $3.4 \mathrm{def}$ & $13.7 \mathrm{ab}$ & $4.9 \mathrm{bc}$ & $4.2 \mathrm{c}$ \\
\hline Kunsmme & Estonia & $23.6 \mathrm{~b}$ & $2.3 \mathrm{ab}$ & $0.0 \mathrm{a}$ & $12.0 \mathrm{a}$ & $3.6 \mathrm{~b}$ & $0.0 \mathrm{a}$ \\
\hline
\end{tabular}

Note. Values within a column followed by the same letter are not significantly different $(P>0.05)$.

Hydroponic screening method. A significant cultivar and $\mathrm{Al}$ interaction was detected for the variable root length in the analysis of variance (ANOVA). It is clear that all cultivars exhibited a very similar behaviour in response to the variation of $\mathrm{Al}$ concentrations. In a more accurate analysis, it can be viewed through plotting of the mean values of root length that differed most at 0 and $50 \mu \mathrm{M}$ concentrations of $\mathrm{Al}$. The root length significantly differed at other concentrations. However, the hypocotyl length differed less at 0 and $5 \mu \mathrm{M} \mathrm{AlCl}_{3}$. Nevertheless, significant differences between hypocotyl lengths were determined at all concentrations (Table 3 ).

The differences in root and hypocotyl lengths at the different concentrations allow the diversity between various cultivars to be assessed. It can be inferred that the concentrations of 25 and $50 \mu \mathrm{M} \mathrm{AlCl}$ were very toxic, resulting in very noticeable damage to the root and hypocotyl length of all cultivars. The root and hypocotyl lengths significantly differed at $25 \mu \mathrm{M} \mathrm{AlCl}_{3}$, they were 1.6 and 1.2 times lower, respectively, and 2.0 and 1.4 times lower at $50 \mu \mathrm{M} \mathrm{AlCl}_{3}$ compared with the control treatment $\left(0 \mu \mathrm{M} \mathrm{AlCl}_{3}\right)$ (Table 3).

The highest $50 \mu \mathrm{M} \mathrm{AlCl}{ }_{3}$ concentration was the most effective for selection of cultivars. Some cultivars appeared to be less affected by the highest $\mathrm{Al}$ concentration. The growth of 'Ellerskie I', 'Elda' and 'Mriia odes'ka' was least impacted at $50 \mu \mathrm{M} \mathrm{AlCl}_{3}$, their root length was 21.2, 19.6 and $21.7 \mathrm{~mm}$, respectively. The hypocotyl length of 'Žydrūnè', 'Romagnola' and 'Viktoria' was the longest - 20.7, 18.4 and $19.7 \mathrm{~mm}$, respectively, and least affected by $\mathrm{Al}$ at $50 \mu \mathrm{M} \mathrm{AlCl}$ (Table 5).

According to Leônidas et al. (2012), the main $\mathrm{Al}$ damage to plant development is primarily related to cell death of the tissues in direct contact with the toxic element, in this case roots, which, therefore, should exhibit more pronounced symptoms of toxicity of this metal. The slower growth of the seedling aerial part occurs due to side effects related to the observed lower root development (Zhang et al., 2007). When comparing

Table 5. The root and hypocotyl length $(\mathrm{mm})$ of Medicago sativa using hydroponic screening method

\begin{tabular}{|c|c|c|c|c|c|c|c|}
\hline \multirow{3}{*}{ Cultivar } & \multirow{3}{*}{$\begin{array}{l}\text { Country } \\
\text { of origin }\end{array}$} & \multicolumn{6}{|c|}{$\mathrm{AlCl}_{3} \mu \mathrm{M}$ concentration } \\
\hline & & 0 & 25 & 50 & 0 & 25 & 50 \\
\hline & & \multicolumn{3}{|c|}{ root length } & \multicolumn{3}{|c|}{ hypocotyl length } \\
\hline Ellerskie I & Canada & 38.4 def & $21.8 \mathrm{~b}-\mathrm{e}$ & $21.2 \mathrm{~cd}$ & $26.9 \mathrm{ef}$ & $19.3 \mathrm{bcd}$ & $17.6 \mathrm{bcd}$ \\
\hline Birutè & Lithuania & $31.9 \mathrm{bcd}$ & $19.0 \mathrm{ab}$ & $18.5 \mathrm{bcd}$ & $27.3 \mathrm{ef}$ & $22.0 \mathrm{de}$ & $17.0 \mathrm{bcd}$ \\
\hline Žydrūnè & Lithuania & $35.1 \mathrm{cde}$ & $24.5 \mathrm{de}$ & $17.0 \mathrm{bc}$ & $29.2 \mathrm{f}$ & $23.2 \mathrm{e}$ & $20.7 \mathrm{~d}$ \\
\hline Juurlu & Estonia & $38.5 \mathrm{def}$ & $20.3 \mathrm{a}-\mathrm{d}$ & $16.7 \mathrm{bc}$ & $16.6 \mathrm{a}$ & $15.6 \mathrm{a}$ & $15.0 \mathrm{ab}$ \\
\hline Alina & Romania & $43.7 \mathrm{f}$ & $25.8 \mathrm{e}$ & $18.8 \mathrm{~cd}$ & $17.5 \mathrm{a}$ & $14.4 \mathrm{a}$ & $11.4 \mathrm{a}$ \\
\hline Magnat & Romania & $41.3 \mathrm{ef}$ & $26.3 \mathrm{e}$ & $16.9 \mathrm{bc}$ & $20.6 \mathrm{abc}$ & $16.1 \mathrm{ab}$ & $15.3 \mathrm{abc}$ \\
\hline Elda & Estonia & 40.0 ef & $20.8 \mathrm{a}-\mathrm{d}$ & $19.6 \mathrm{~cd}$ & $21.6 \mathrm{bcd}$ & $16.1 \mathrm{ab}$ & $15.3 \mathrm{abc}$ \\
\hline Adin & Romania & $28.9 \mathrm{abc}$ & $16.2 \mathrm{a}$ & $11.9 \mathrm{a}$ & $22.0 \mathrm{bcd}$ & $17.4 \mathrm{abc}$ & $14.4 \mathrm{ab}$ \\
\hline Mriia odes'ka & Ukraine & $27.8 \mathrm{ab}$ & $21.7 \mathrm{~b}-\mathrm{e}$ & $21.7 \mathrm{~d}$ & $24.8 \mathrm{de}$ & $21.9 \mathrm{de}$ & $17.1 \mathrm{bcd}$ \\
\hline Romagnola & Italy & $28.6 \mathrm{abc}$ & $19.9 \mathrm{abc}$ & $16.8 \mathrm{bc}$ & 24.4 cde & $21.1 \mathrm{de}$ & $18.4 \mathrm{bcd}$ \\
\hline Viktoria & Czech Republic & $32.1 \mathrm{bcd}$ & $20.3 \mathrm{a}-\mathrm{d}$ & $14.1 \mathrm{ab}$ & $24.7 \mathrm{de}$ & 20.3 cde & $19.7 \mathrm{~cd}$ \\
\hline Magda & Czech Republic & $24.6 \mathrm{a}$ & $17.6 \mathrm{ab}$ & $17.6 \mathrm{bcd}$ & $18.3 \mathrm{ab}$ & $17.5 \mathrm{abc}$ & $15.5 \mathrm{abc}$ \\
\hline Kunsmme & Estonia & $37.7 \mathrm{def}$ & 23.8 cde & $17.6 \mathrm{bcd}$ & $20.4 \mathrm{ab}$ & $17.2 \mathrm{abc}$ & $16.3 \mathrm{bcd}$ \\
\hline
\end{tabular}

Note. Values within a column followed by the same letter are not significantly different $(P>0.05)$. 
the results of root and hypocotyl elongation among all cultivars in the absence of Al stress, 'Birute', 'Mriia odes'ka', 'Romagnola' and 'Magda' showed the best performance. The root tolerance index of these cultivars was $58.0,78.2,58.7$ and $71.4 \%$, respectively at $50 \mu \mathrm{M}$ $\mathrm{AlCl}_{3}$ compared with the control treatment $(0 \mu \mathrm{M}$ $\mathrm{AlCl}_{3}$ ) (Fig. C). However, the hypocotyl length was very similar and ranged from 11.4 to $20.7 \mathrm{~mm}$ at $50 \mu \mathrm{M}$ $\mathrm{AlCl}_{3}$ (Table 5). Cultivars 'Žydrūnè', 'Juurlu', 'Magnat', 'Romagnola', 'Viktoria', 'Magda' and 'Kunsmme' showed the best performance for hypocotyl length. The hypocotyl tolerance index of these cultivars ranged from $70.7 \%$ to $85.0 \%$ compared with the control treatment $(0 \mu \mathrm{M} \mathrm{AlCl})$ (Fig. D).

Soil-based screening method in greenhouse conditions. Acid soils affect the plant growth by altering various physiological processes (Skuodienè et al., 2017; Tomchuk, 2018). External $\mathrm{pH}$ affects the root growth by causing a severe reduction in shoot and root growth of $M$. sativa and other plants. According to Zhou et al. (2016), with respect to root growth three responses can be observed depending on the concentration of Al. The $\mathrm{Al}$ concentrations in the soil with $\mathrm{pH} 4.5$ and $\mathrm{pH} 4.3$ were very toxic for root and hypocotyl growth (Table 1). The length of root and hypocotyl was significantly 1.4 and 2.6 times lower at $\mathrm{pH} 4.5$, respectively compared with the control treatment at $\mathrm{pH}$ 7.2. Also, there were determined differences between lengths of roots and hypocotyls $(2.8$ and 3.9 times lower, respectively) at $\mathrm{pH} 4.3$ compared with the control soil pH 7.2 (Table 3).
The hypocotyls of cultivars were more inhibited by Al toxicity, hypocotyl length ranged from 2.0 to $3.8 \mathrm{~cm}$ at $\mathrm{pH} 4.3$. However, hypocotyl length significant differed at $\mathrm{pH} 4.5$, it ranged from 2.9 to $7.2 \mathrm{~cm}$. The significant differences in hypocotyl length among the tested M. sativa cultivars are shown in Table 6. The hypocotyl growth depended on growth and development of roots and cultivars' reaction to Al toxicity.

In acid soils, the toxicity of $\mathrm{Al}$ affected growth and development of roots. The growth and development of hypocotyls depended on root development. At the same time Al toxicity affected the length of hypocotyls. The root and hypocotyl lengths were significantly 2.0 and

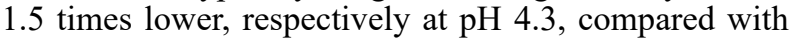
$\mathrm{pH} 4.5$ (Table 3 ). The cultivar and $\mathrm{Al}$ interaction showed that the lengths of roots and hypocotyls depended more on the cultivars' reaction to Al toxicity under different soil $\mathrm{pH}$ levels (Table 2 ).

The results of the current experiment also demonstrated the variation in $M$. sativa cultivars for tolerance to soil $\mathrm{pH}$. Clearly lower response to Al toxicity was detected in 'Žydrūne' and 'Magnat' - the roots were the longest $(12.5 \mathrm{~cm})$ at $4.5 \mathrm{pH}$ compared with the other cultivars tested. A lower response to Al toxicity was also observed in 'Ellerskie', 'Žydrūne', 'Alina', 'Magnat', 'Mriia odes'ka', 'Romagnola' and 'Kunsmme'. The root length of these cultivars was similar - it ranged from 5.4 to $5.9 \mathrm{~cm}$ at $\mathrm{pH} 4.3$ (Table 6). However, stronger $\mathrm{Al}$ toxicity was seen at $\mathrm{pH} 4.5$ (Table 6 ). About $69.2 \%$ of cultivars were more damaged by $\mathrm{Al}$ toxicity at $\mathrm{pH}$ 4.5.

Table 6. The root and hypocotyl length $(\mathrm{cm})$ of Medicago sativa under soil-based screening method in greenhouse conditions

\begin{tabular}{|c|c|c|c|c|c|c|c|}
\hline \multirow{3}{*}{ Cultivar } & \multirow{3}{*}{$\begin{array}{l}\text { Country } \\
\text { of origin }\end{array}$} & \multicolumn{6}{|c|}{ pH of soil } \\
\hline & & 7.2 & 4.5 & 4.3 & 7.2 & 4.5 & 4.3 \\
\hline & & \multicolumn{3}{|c|}{ root length } & \multicolumn{3}{|c|}{ hypocotyl length } \\
\hline Ellerskie I & Canada & $17.2 \mathrm{~b}$ & $9.7 \mathrm{ab}$ & $5.4 \mathrm{~cd}$ & $13.6 \mathrm{bcd}$ & $6.3 \mathrm{de}$ & $3.8 \mathrm{~b}$ \\
\hline Birutè & Lithuania & $14.8 \mathrm{ab}$ & $10.1 \mathrm{ab}$ & $4.9 \mathrm{bc}$ & $14.6 \mathrm{~d}$ & $4.9 \mathrm{bcd}$ & $2.5 \mathrm{ab}$ \\
\hline Žydrūnè & Lithuania & $15.5 \mathrm{ab}$ & $12.5 \mathrm{~d}$ & $5.6 \mathrm{~cd}$ & $12.7 \mathrm{abcd}$ & 5.5 cde & $2.7 \mathrm{ab}$ \\
\hline Juurlu & Estonia & $12.7 \mathrm{a}$ & $11.9 \mathrm{~cd}$ & $6.3 \mathrm{~d}$ & $7.8 \mathrm{a}$ & $3.4 \mathrm{ab}$ & $3.4 \mathrm{ab}$ \\
\hline Alina & Romania & $14.2 \mathrm{ab}$ & $8.9 \mathrm{a}$ & $5.7 \mathrm{~cd}$ & $12.8 \mathrm{bcd}$ & $4.2 \mathrm{abc}$ & $3.4 \mathrm{ab}$ \\
\hline Magnat & Romania & $15.4 \mathrm{ab}$ & $12.5 \mathrm{~d}$ & $5.4 \mathrm{~cd}$ & $11.6 \mathrm{abcd}$ & $4.7 \mathrm{abcd}$ & $3.3 \mathrm{ab}$ \\
\hline Elda & Estonia & $14.0 \mathrm{ab}$ & $10.3 \mathrm{ab}$ & $4.0 \mathrm{ab}$ & $13.9 \mathrm{bcd}$ & $7.2 \mathrm{e}$ & $2.6 \mathrm{ab}$ \\
\hline Adin & Romania & $14.8 \mathrm{ab}$ & $9.9 \mathrm{ab}$ & $5.0 \mathrm{bc}$ & $13.5 \mathrm{bcd}$ & $2.9 \mathrm{a}$ & $2.7 \mathrm{ab}$ \\
\hline Mriia odes'ka & Ukraine & $14.1 \mathrm{ab}$ & $10.3 \mathrm{ab}$ & $5.9 \mathrm{~cd}$ & $9.5 \mathrm{abc}$ & $4.3 \mathrm{abc}$ & $3.2 \mathrm{ab}$ \\
\hline Romagnola & Italy & $14.3 \mathrm{ab}$ & $9.6 \mathrm{ab}$ & $5.5 \mathrm{~cd}$ & $11.6 \mathrm{abcd}$ & $3.9 \mathrm{abc}$ & $3.6 \mathrm{ab}$ \\
\hline Viktoria & Czech Republic & $13.8 \mathrm{ab}$ & $10.8 \mathrm{bc}$ & $4.3 \mathrm{ab}$ & $14.3 \mathrm{~cd}$ & 5.7 cde & $3.7 \mathrm{~b}$ \\
\hline Magda & Czech Republic & $13.2 \mathrm{a}$ & $10.7 \mathrm{bc}$ & $3.6 \mathrm{a}$ & $13.2 \mathrm{bcd}$ & $4.6 \mathrm{abcd}$ & $2.0 \mathrm{a}$ \\
\hline Kunsmme & Estonia & $15.1 \mathrm{ab}$ & $10.9 \mathrm{bc}$ & $5.6 \mathrm{~cd}$ & $9.3 \mathrm{ab}$ & $4.0 \mathrm{abc}$ & $3.1 \mathrm{ab}$ \\
\hline
\end{tabular}

Note. Within a column values followed by the same letter are not significantly different $(P>0.05)$.

The hypocotyls of the 'Ellerskie I', ‘Žydrūnè', 'Elda' and 'Viktoria' were significantly 1.5 times longer compared with those of the other cultivars. The hypocotyl length of these cultivars ranged from 5.5 to $7.2 \mathrm{~cm}$ at $\mathrm{pH} 4.5$ and from 2.5 to $3.8 \mathrm{~cm}$ at $\mathrm{pH} 4.3$. However, the hypocotyl length of these cultivars significantly differed from that of the cultivar 'Magda' (Table 6). The root and hypocotyl lengths were similar (14.5 and $12.2 \mathrm{~cm}$, respectively) at pH 7.2 (Table 3).

The root lengths of cultivars less differed by resistance for $\mathrm{Al}$ toxicity at $\mathrm{pH} 4.5$. Therefore, selection of the most resistant cultivars at $\mathrm{pH} 4.5$ was very difficult, because the root tolerance index was very similar and high, and ranged from $56.7 \%$ to $93.8 \%$. The cultivars were more exposed to Al toxicity stress at $\mathrm{pH} \mathrm{4.3.} \mathrm{The}$ 'Juurlu', 'Alina', 'Mriia odes'ka', 'Romagnola' and 'Kunsmme' were characterised by the root tolerance index. The root tolerance index of these cultivars was similar and ranged from $37.40 \%$ to $49.22 \%$ (Fig. E). The 'Juurlu', 'Mriia odes'ka', 'Romagnola' and 'Kunsmme' showed the best hypocotyl tolerance index ranging from $31.0 \%$ to $43.6 \%$ (Fig. F).
The Al and cultivar interaction revealed that $\mathrm{Al}$ influenced the growth of roots and hypocotyls of the $M$. sativa cultivars and showed that these traits can be used in selection. It has been demonstrated that cultivars selected for superior root and hypocotyl growth using filter paper-based, hydroponic and soil-based methods, also confer significant increases in root growth in highly acidic soil that is high in mobile $\mathrm{Al}$ (Choudhary et al., 2011).

The most resistant seedlings at early plant stage of development can be screened quickly using a filter paper-based method. Significant correlations between hypocotyl lengths at different concentrations of $\mathrm{Al}$ $(r=0.575-0.726, P<0.01)$ showed strongly inhibited hypocotyl growth in the filter-paper based method. Also, the growth of roots was strongly affected by the toxicity of Al using this method. This was indicated by significant correlations between root lengths at different $\mathrm{Al}$ concentrations $(r=0.555-0.8, P<0.01)$. The effect of Al toxicity on root and hypocotyl growth was seen using the hydroponics method. Correlation coefficients between roots and between hypocotyls were determined at different concentrations of $\mathrm{Al}(r=0.582-0.872, P<0.01$, 
and $r=0.586-0.918, P<0.01$, respectively). The effect of Al toxicity was seen using the soil-based method. This was shown by the mean correlation between root and hypocotyl lengths $(r=0.573, P<0.01)$ at $\mathrm{pH} 4.3$.

The root and hypocotyl length and other parameters could be used to assess Al tolerance, but selection of resistant roots and hypocotyls was slow in acidic soils. The processes taking place in the root react very strongly to the toxicity of Al during growth. The process of root development takes a long time by studying resistance under a soil-based method. The development of roots depended on successful nodulation and rhizobium in acidic soil conditions. Therefore, improved $M$. sativa nodulation will most likely be achieved thought the selection of compatible rhizobium in acidic soil and selection of $M$. sativa plants for increased capacity to nodulate in acidic conditions (Charman et al., 2008; Hayes et al., 2011). Root development (elongation and absorption), translocation and utilization of nutrients may make major differences in tolerant and intolerant cultivars to acid soils. Cultivars that are efficient nutrient utilizers might be useful in breeding for more efficient cultivars for mineral-stressed-acid soils (Gupta et al., 2013; Bose et al., 2015).

The screening methods tested demonstrated that the Al toxicity influenced development and growth of roots and hypocotyls of $M$. sativa. Different root and hypocotyl lengths obtained by studying different methods allowed the selection of resistant material as described in the literature (Pan et al., 2008; Hayes et al., 2011; Khu et al., 2012). However, the hydroponic method was effective in that it was possible to estimate seedling length as well as adult seedling growth in other methods (Köpp et al., 2011). The latter methods, especially soil-based screening, are hardly suitable for screening of thousands of seeds per cultivar. However, these methods could be successfully applied for the final screening steps, when several populations have been selected after multiple cycles of recurrent selection.

Development of $M$. sativa breeding populations requires evaluating and selecting several hundreds of plants with desired agronomic traits. Cultivars originating in the countries with hot and dry climates are usually crossed with that originating in Europe. The results of the experiment revealed that 'Mriia odes'ka' and 'Romagnola' are more suitable for crossbreeding with other cultivars from Lithuania, Estonia, Czech Republic and Romania.

\section{Conclusions}

1. The results of the experiment suggested that root and hypocotyl length of Medicago sativa was most influenced by aluminium (Al) toxicity at 8 and $16 \mathrm{mM}$ $\mathrm{AlCl}_{3}$ (aluminium chloride) using the filter paper-based screening method. The root and hypocotyl tolerance index was $17.2 \%$ and $32.5 \%$ lower at $8 \mathrm{mM} \mathrm{AlCl}_{3}$ and $9.6 \%$ and $8.0 \%$ lower at $16 \mathrm{mM} \mathrm{AlCl}_{3}$ compared with the control treatment $\left(0 \mathrm{mM} \mathrm{AlCl}_{3}\right)$. Of the 13 investigated cultivars, 'Birute', 'Žydrūnè' and 'Magda' were found to be the most tolerant to $\mathrm{Al}$ toxicity at $16 \mathrm{mM} \mathrm{AlCl}_{3}$.

2 . The root growth and elongation were more inhibited by $\mathrm{Al}$ toxicity compared with hypocotyl growth at $50 \mu \mathrm{M} \mathrm{AlCl}{ }_{3}$ using the hydroponic screening method. The root and hypocotyl tolerance index was $52.2 \%$ and $73.3 \%$ lower, respectively at $50 \mu \mathrm{M} \mathrm{AlCl}_{3}$ compared with the control treatment $\left(0 \mu \mathrm{M} \mathrm{AlCl}_{3}\right)$. Cultivar 'Magda' was distinguished by the longest hypocotyl and root lengths at $50 \mu \mathrm{M} \mathrm{AlCl}_{3}$.

3. The growth of hypocotyls was by 1.4 times lower compared with root growth at soil $\mathrm{pH} 4.3 \mathrm{using}$ the soil-based screening method. The root and hypocotyl tolerance index was $73.5 \%$ and $39.3 \%$ at $\mathrm{pH} 4.5$, and
$35.6 \%$ and $26.3 \%$ at $\mathrm{pH} 4.3$ compared with $\mathrm{pH} 7.2$. The cultivars 'Juurlu', 'Mriia odes'ka', 'Romagnola' and 'Kunsmme' were distinguished by the longest hypocotyl and root length at $\mathrm{pH} 4.3$.

4. The results of this experiment showed that the filter paper-based and hydroponic methods can be used at early stage of development of seedlings to focus selection on cultivars that are responding specially to Al toxicity. The soil-based method is more stringent than either the filter-paper based or hydroponic methods for $M$. sativa. The most tolerant to Al toxicity cultivars 'Birutè', 'Magda', 'Magnat', 'Romagnola', 'Juurlu' and 'Mriia odes'ka' under laboratory conditions could grow in acid soil under natural conditions. A large percentage of plants resistant to acid soils of these cultivars can be used for the development of new accessions.

\section{Acknowledgments}

The paper presents research findings, obtained through the long-term research programme "Genetic and purposeful change of genotypes of agricultural and forest plants" implemented by Lithuanian Research Centre for Agriculture and Forestry.

Received 14112019

Accepted 16072020

\section{References}

1. Arunakumara K. K. I. U., Walpola B. C., Yoon M. H. 2013. Aluminum toxicity and tolerance mechanism in cereals and legumes - a review. Journal of the Korean Society for Applied Biological Chemistry, 56: 1-9.

https://doi.org/10.1007/s13765-012-2314-z

2. Bose J., Babourina O., Ma Y., Zhou M., Shabala S., Rengel Z. 2015. Specificity of ion uptake and homeostasis maintenance during acid and aluminium stresses. Panda S., Baluška F. (eds). Aluminum stress adaptation in plants. Signaling and communication in plants, vol. 24. Springer, p. 229-251. https://doi.org/10.1007/978-3-319-19968-9 12

3. Bouton J. H. 2012. Breeding lucerne for persistence. Crop Pasture Science, 63 (2): 95-106. https://doi.org/10.1071/CP12009

4. Charman N., Ballard R. A., Humphries A. W., Auricht G. C. 2008. Improving lucerne nodulation at low $\mathrm{pH}$ : contribution of rhizobia and plant genotype to the nodulation of lucerne seedlings growing in solution culture at $\mathrm{pH} 5$. Australian Journal of Experimental Agriculture, 48: 512-517. https://doi.org/10.1071/EA07138

5. Choudhary A. K., Singh D., Kumar J. 2011. A comparative study of screening methods for tolerance to aluminium toxicity in pigeonpea (Cajanus cajan (L.) Millspaugh). Australian Journal of Crop Science, 5 (11): 1419-1426.

6. Gupta N., Gaurav S. S., Kumar A. 2013. Molecular basis of aluminium toxicity in plants: a review. American Journal of Plant Sciences, 4: 21-37.

https://doi.org/10.4236/ajps.2013.412A3004

7. Haling R. E., Simpson R. J., Culvenor R. A., Lambers H., Richardson A. E. 2011. Effect of soil acidity, soil strength and macropores on root growth and morphology of perennial grass species differing in acid-soil resistance. Plant Cell and Environment, 34 (3): 444-456. https://doi.org/10.1111/j.1365-3040.2010.02254.x

8. Hayes R. C., Scott B. J., Dear B. S., Li G. D., Auricht G. C. 2011. Seedling validation of acid soil tolerance of lucerne populations selected in solution culture high in aluminium. Crop and Pasture Science, 62: 803-811. https://doi.org/10.1071/CP11093

9. Idupulapati M. R., John W. M., Stephen E. B., Walter J. H. 2016. Root adaptations to soils with low fertility and aluminium toxicity. Annals of Botany, 118: 593-605. https://doi.org/10.1093/aob/mcw073

10. Khu D. M., Reyno R., Brummer E. C., Monteros M. J. 2012. Screening methods for aluminum tolerance in alfalfa. Crop Science, 52: 161-167. https://doi.org/10.2135/cropsci2011.05.0256

11. Khu D. M., Reyno R., Han Y., Zhao P. X., Bouton J. H., Brummer E. C., Monteros M. J. 2013. Identification of aluminum tolerance quantitative trait loci in tetraploid alfalfa. Crop Science, 53: 148-163. https://doi.org/10.2135/cropsci2012.03.0181 
12. Kochian L., Piñeros M. A., Liu J., Magalhaes J. V. 2015. Plant adaptation to acid soils: the molecular basis for crop aluminium resistance. Annual Review of Plant Biology, 66: 571-598.

https://doi.org/10.1146/annurev-arplant-043014-114822

13. Köpp M. M., Passos L. P., Verneue R. D. S., Lédo F. J. D. S., Coimbra J. L. M., Oliveira A. C. 2011. Effects of nutrient solution $\mathrm{pH}$ on growth parameters of alfalfa (Medicago sativa L.) genotypes. Comunicata Sientiae, 2 (3): 135-141.

14. Leônidas P. P., Köpp M. M., Lédo F. J. S. 2012. Performance of tetraploid alfalfa genotypes as exposed to aluminium toxicity. Agricultural Sciences, 3 (2): 230-240. https://doi.org/10.4236/as.2012.32027

15. Meriño-Gergichevich C., Alberdi M., Ivanov A. G., ReyesDiaz M. 2010. $\mathrm{Al}^{3+}-\mathrm{Ca}^{2+}$ interaction in plants growing in acid soils: Al-phytotoxicity response to calcareous amendments. Journal of Soil Science and Plant Nutrition, 10 (3): $217-243$.

16. Narasimhamoorthy B., Blancaflor E. B., Bouton J. H. Payton M. E., Sledge M. K. 2007. A comparison of hydroponics, soil, and root staining methods for evaluation of aluminum tolerance in Medicago truncatula (barrel medic) germplasm. Crop Science, 47 (1): 321-328. https://doi.org/10.2135/cropsci2006.03.0147

17. Pan X. B., Zhu C., Cheng C. 2008. Assessment of techniques for screening alfalfa cultivars for aluminium tolerance. Euphytica, 164 (2): 541-549. https://doi.org/10.1007/s10681-008-9751-0

18. Petcu E., Schitea M., Badea D. 2006. The response of some Romanian alfalfa genotypes to soil acidity. Romanian Agricultural Research, 23: 25-27.

19. Rao I. M. 2014. Advances in improving adaptation of common bean and Brachiaria forage grasses to abiotic stresses in the tropics. Pessarakli M. (ed.). Handbook of plant and crop physiology ( $3^{\text {rd }}$ ed.). CRC Press, p. 847-889. https://doi.org/10.1201/b16675-49

20. Sabanci C. O., Ertus M. M., Zorer Celebi S. 2013. Collection, conservation and evaluation for forage yield of alfalfa landraces grown in East Anatolia. Turkish Journal of Field Crops, 18 (1): 46-51.
21. Scheffer-Basso S. M., Priori B. C. 2015. Aluminum toxicity in roots of legume seedlings assessed by topological analysis. Acta Scientiarum Agronomy, 37 (1): 61-68. https://doi.org/10.4025/actasciagron.v37i1.18362

22. Skuodienè R Tomchuk D., Aleinikovienè J. 2017. Plant root morphology and soil biological indicators under primary development of various swards. Acta Agriculturae Scandinavica, Section B: Plant Soil Science, 67 (5): 435$443 \mathrm{https}: / /$ doi.org/10.1080/09064710.2017.1293724

23. Tomchuk D. 2018. Grassland belowground biomass and organic carbon accumulation in different terrain ecosystems: doctoral dissertation. Lithuanian Research Centre for Agriculture and Forestry, $132 \mathrm{p}$.

24. WRB. 2014. World reference base for soil resources. World Soil Resources Reports No. 106. FAO, 189 p.

25. Yang Z. B., Rao I. M., Horst W. J. 2013. Interaction of aluminium and drought stress on root growth and crop yield on acid soils. Plant and Soil, 372: 3-25. https://doi.org/10.1007/s11104-012-1580-1

26. York L. M., Nord E. A., Lynch J. P. 2013. Integration of root phenes for soil resource acquisition. Frontiers in Plant Science, 4 (355): 1-15.

https://doi.org/10.3389/fpls.2013.00355

27. Zhang X., Humphries A., Auricht G. 2007. Genetic variability and inheritance of aluminium tolerance as indicated by long root regrowth in lucerne (Medicago sativa L.). Euphytica, 157 (1-2): 177-184. https://doi.org/10.1007/s10681-007-9409-3

28. Zhang H., Jiang Z., Qin R., Zhang H., Zou J., Jiang W., Liu D. 2014. Accumulation and cellular toxicity of aluminum in seedling of Pinus massoniana. BMC Plant Biology, 14: 264. https://doi.org/10.1186/s12870-014-0264-9

29. Zhou S., Okekeogbu I., Sangireddy S., Ye Z., Li H., Bhatti S., Hui D., McDonald D. W., Yang Y., Giri S., Howe J.' K., Fish T., Thannhauser T. W. 2016. Proteome modification in tomato plants upon long-term aluminium treatment. Journal Proteome Research, 15 (5): 1670-1684. https://doi.org/10.1021/acs.jproteome.6b00128

ISSN 1392-3196 / e-ISSN 2335-8947

Zemdirbyste-Agriculture, vol. 107, No. 4 (2020), p. 309-316

DOI $10.13080 / \mathrm{z}-\mathrm{a} .2020 .107 .039$

\title{
Medicago sativa atsakas ị judriojo aliuminio toksiškumą daigelių tarpsniu
}

\author{
A. Liatukiené ${ }^{1}$, V. Ruzgas ${ }^{1}$, Ž. Liatukas ${ }^{1}$, R. Skuodienè ${ }^{2}$ \\ ${ }^{1}$ Lietuvos agrarinių ir miškų mokslų centro Žemdirbystès institutas \\ ${ }^{2}$ Lietuvos agrarinių ir miškų mokslų centro Vėžaičių filialas
}

\section{Santrauka}

Rūgščiuose dirvožemiuose pasèlių produktyvumą labiausiai riboja judriojo aliuminio (Al) toksiškumas. Tyrimo tikslas - ịvertinti mėlynžiedès ir margažiedès liucernų (Medicago sativa L.) veislių vystymąsi ir atsaką i judriojo Al toksiškumą. Tyrimo metu, taikant tris atrankos metodus: Petri lèkštelių, hidroponikos ir vegetacinių bandymų, buvo vertinta 13 veislių $M$. sativa tolerancija judriajam Al. Analizuoti biologiniai rodikliai: hipokotilių ilgis, šaknų ilgis ir hipokotilių bei šaknų ilgių tolerantiškumo indeksai. Toksinis judriojo Al poveikis pasireiškè visiems $M$. sativa biologiniams rodikliams; tai rodo koreliaciniai ryšiai tarp biologinių rodikliu ir atrankos metodų. Taikant Petri lèkštelių atrankos metodą $\left(16 \mathrm{mM} \mathrm{AlCl}_{3}\right)$, šaknų ir hipokotilių ilgių tolerantiškumo indeksai svyravo atitinkamai nuo 0,0 iki $23,2 \%$ ir nuo 0,0 iki 37,2\%. Hidroponikos ir vegetaciniuose bandymuose rūgščiame dirvožemyje M. sativa veislès labiau skyrèsi tolerantiškumu judriojo Al toksiškumui. Taikant hidroponikos metodą (50 $\mu \mathrm{M}$ $\mathrm{AlCl}_{3}$ ), hipokotilių ir šaknų ilgių tolerantiškumo indeksai pakilo nuo 41,0 iki 78,2 \% ir nuo 62,1 iki 90,2 \%. Rūgščiame dirvožemyje, kurio pH 4,5 ir 4,3, hipokotiliai buvo labiau paveikti Al toksiškumo nei šaknys. Rūgščiame dirvožemyje, kurio pH 4,5, šaknų ir hipokotilių ilgių tolerantiškumo indeksai buvo 73,5 ir 39,3 \%, o dirvožemyje, kurio pH 4,3-35,6 ir 26,3\%. Veislès 'Mriia odes'ka', 'Romagnola', 'Kunsmme' ir 'Juurlu' išsiskyrè hipokotilių ir šaknų tolerantiškumo indeksais hidroponikos bei vegetaciniuose bandymuose rūgščiame dirvožemyje.

Taikant Petri lèkštelių ir hidroponikos atrankos metodus, veislès 'Žydrūnè', 'Birutè', 'Magnat', 'Viktoria' bei 'Magda' išsiskyrè hipokotilių ir šaknų tolerantiškumo indeksais. Šios veislès laikomos tolerantiškomis ir gali būti panaudotos kaip donorai kuriant judriajam $\mathrm{Al}$ atsparius genotipus ir vykdant tolesnę $M$. sativa atsparumo judriajam Al selekciją.

Reikšminiai žodžiai: liucerna, aliuminio toksiškumas, hipokotilis, šaknis, atrankos metodas, tolerancijos indeksas. 